\title{
On Different Perspective: Image of Yogyakarta as a Tourist Destination from Domestic and International Tourist's Perception
}

\author{
Karlina Maizida* \\ Faculty of Cultural Sciences, Universitas Gadjah Mada, Indonesia \\ *Corresponding Author:karlina.maizida@ugm.ac.id \\ DOI: https://doi.org/10.24922/eot.v8i1.69741
}

Article Info
Submitted
January $24^{\text {th }} 2021$
Accepted
March $18^{\text {th }} 2021$
Published
March $31^{\text {th }} 2021$

Article Info

\begin{abstract}
This study examines the differences in how domestic and international tourists perceived the image of Yogyakarta as a tourist destination. This survey-based quantitative research used online-questionnaire to collect data from the domestic and international tourists who have visited Yogyakarta. Using a non-probability convenience sampling method, 304 useable questionnaire responses were collected through any social media network. The image of Yogyakarta as a tourist destination in this study consists of four parts: top of mind image, destination visual image selection, cognitive and affective evaluation. To test the different perspectives about cognitive and affective components of an image between domestic and international tourists, a non-parametric MannWhitney u-test was performed. The result shows that there is a significant difference in cognitive evaluation about an image of Yogyakarta as a destination nevertheless, no significant difference was found in the affective evaluation. The differences also appeared in the part of visual image selection whereas domestic tourists mostly choose Malioboro as the best picture to describe Yogyakarta while international tourists choose a Temple more than others. At the top-of-mind, international tourists mentioned Borobudur as a part of heritage sites and history frequently while most domestic tourists mentioned art and culture, shopping, and culinary. Furthermore, a methodological issue and practical implication are also discussed.
\end{abstract}

Keywords: destination image, domestic and international tourist, Yogyakarta, Indonesia

\section{INTRODUCTION}

An image that a person holds on something is unique and it depends on both cognitive and emotional factors. Handful research argued an image has contributed to people's choice, motivation, and attitude toward a product or destination (Cooper et al., 2008). Research about tourist desti- nation image has broadly been conducted, many have shown that it is the crucial factor in selecting a destination to visit (Hunter, 2008). In the past thirty years, destination image is a subject that successfully gained attention of many scholars because of its dynamic argument on the conceptual framework and methodology (Gallarza, Saura and García, 2002). Research shows 
destination image has a positive correlation with visit intention (Chen \& Tsai, 2007; Prayag \& Ryan, 2012). Many tried to examine factors or attributes influence image (Baloglu \& Brinberg, 1997; Fakeye \& Crompton, 1991), some of them tried to investigate destination image from a different perspective such as domestic and international visitors (Bonn et al., 2005; Quintal et al., 2014; Stone \& Nyaupane, 2019), as well as resident and tourist (Slak Valek and Williams, 2018). Comparative research about imaged has shown that tourist perception about the destination has propensity depend on national or country of origin, cultural differences, and their geographic origin (Bonn et al., 2005; Law et al., 2007; Quintal et al., 2014). Moreover, those comparative research about image generally emphasize that the image of destination may differ from one person to another. Understanding the image of a destination from various perspectives enables tourism planning and development more precisely. It is the first study that the main purpose is to examine the different perceptions of destination image from domestic and international tourists in one of the major tourist destinations in Indonesia, Yogyakarta Special Region.

Research indicated that elements of the tourist industry spend a huge amount of money in an effort of building an image for their destination (Ross, 1998). It is confidentially said that image is a significant factor to support tourism planning and development and regarded to promoting destination (Tasci, Gartner and Tamer Cavusgil, 2007). This study was conducted for several reasons. First, Yogyakarta is one of the most favourite and popular destinations for domestic tourists. Data showed from 2014-2018 it is always being the big five of most visiting destinations (Biro Pusat Statistik, 2018). More than six million domestic tourists visited Yogyakarta in 2019 and it is beyond the target of the Yogyakar- ta tourism office. Nevertheless, for foreign tourist visitation to Yogyakarta total growth percentage from 2015 to 2019 is getting smaller although the number of tourist visitation is increased (Dinas Pariwisata DIY, 2019). Compare to Bali as the most visiting destination in Indonesia, it was only $5.79 \%$ of total international tourist visited Indonesia came to Yogyakarta while Bali took $43.40 \%$ from total international tourist visitation (Kemenpar, 2018). Subsequently, if we look at the document of the strategic plan of Yogyakarta tourism office it is clearly stated that the government's vision is "Special Region of Yogyakarta in 2025 as the Centre for Education, Culture and Leading Tourist Destinations in Southeast Asia in an Advanced, Independent and Prosperous Society" and to achieve it, one of the missions is to increase the number of domestic and international tourist as well as the length of stay. For the domestic tourist, the visitation number target is achieved. In contrast, for international tourist the number still below the target moreover, the average length of stay for both tourists were still quite short no more than two days (Dinas Pariwisata DIY, 2019). It is shown that Yogyakarta still not become a 'first of mind' tourist destination in Indonesia for international tourists even though it is a remarkable destination for domestic tourists. By this assumption, it is important to investigate how domestic and international tourists perceive an image of Yogyakarta as a tourist destination to decide the right strategies regarded to government's vision.

Another reason this study conducted in Yogyakarta is considered to image that attached to Yogyakarta so far. Yogyakarta has long been knowing as a city of culture, tradition, and a city of students (Santoso, 2019). Aside from that attached image, Yogyakarta truly has various attractions from the natural landscape, heritage sites and buildings as well as cultural events enrich with tremendous history along with 
its existence. Endowed with tremendous potentiality, it is unsurprisingly that the government is preparing Yogyakarta for a prominent international tourist destination. A destination image consists of both positive and negative attributes (Quintal, Phau and Polczynski, 2014). Recently as we can search in any news media, Yogyakarta also deals with congestion and safety issues such as juvenile delinquency, fraud in tourist attractions, and sexual harassment among foreign women tourists. Those incidents will certainly affect the image of Yogyakarta as a tourist destination that is being prepared as an international tourist destination. Not least, like most other tourist destinations around the world during the pandemic, predicting when tourism might recover due to fluctuation of positive case number of Covid-19 is still inconvenient. Along with the government's efforts, this present study is expected to be one of the references to support recovery tourism in Yogyakarta through carrying out proper planning, development, and promotion by understanding the image of Yogyakarta from multiple perspectives. Last, a study conducted about the image of Yogyakarta from the perspective of tourists is limited and some that we can find in literature has done by researchers, (Khairani \& Setyowardhani, 2013; Nurazizah \& Marhanah, 2020; Santoso, 2019) none of them examines the perception of international tourist or comparing both groups. An understanding of destination image in both groups is important as the requirement to develops a tourism destination.

\section{LITERATURE REVIEWS}

\section{Destination Image: Components and At- tributes}

An image is defined as the overall belief, idea, and impression that person holds about a place or destination (Crompton, 1979; Kotler \& Gertner, 2002). It is a men- tal response that an individual has about a place or tourism destination. As a mental response, many scholars suggest that image encompass both cognitive as well as affective components and research which examines both is believed would be more comprehensive (Baloglu \& McCleary, 1999; Gartner, 1994). Cognitive components involve memory or remembering, thinking, attention, selection, and evaluation (Tasci, Gartner and Tamer Cavusgil, 2007). An extensive study about destination image has been doing by researchers to examines various cognitive attributes of image (Gallarza, Saura and García, 2002). Since Mayo (Mayo, 1975) proposed scenery, congestion, and climate as three main attributes of image, more research has been conducted to identified attributes of image in various destinations. Some research also shared same attributes of image. The attributes of image vary from functional like landscape, natural and cultural attractions to more psychological like safety, local people's receptiveness, and quality of service (Gallarza, Saura and García, 2002). More research identified other attributes depend on the existing condition of a destination (Baloglu, 2001; Chen \& Tsai, 2007; Echtner \& Ritchie, 1993). Since a structured approach is common use for destination image research (Ross, 1998), different study about image in different destination uses various attributes from simply 3 attributes to more extensive up to 82 attributes (Tasci, Gartner and Tamer Cavusgil, 2007).

Affective components related to emotion or what do people feel, it could be either positive or negative response about something with varying intensity. It is a continuum from the highest intensity starting from emotions subsequently feeling, followed by moods and at the lowest intensity is attitude or evaluation (Tasci, Gartner and Tamer Cavusgil, 2007). Unlike cognitive attributes of image, the attributes of the affective component have not been ex- 
tensively developed (Echtner and Ritchie, 1993) and one of the concepts we can find developed by Russel and colleagues (Baloglu and Brinberg, 1997) which defined eight attributes or variables of affective component namely pleasant-unpleasant, exciting-distressing, arousing-sleepy and relaxing-distressing. Another study found that affective components have three dimensions which are captivating, exciting, and relaxing (Coban S, 2012).

\section{Top of Mind Image}

Many image researchers developed an approach for studying image that more multi-methods than common use like semantic differential and Likert scale, to gain a better understanding of tourist's perception (Konecnik \& Gartner, 2007; Slak Valek \& Williams, 2018; Stepchenkova \& Li, 2014). An unstructured approach to study image used in 1993 (Echtner and Ritchie, 1993) proposed three open-ended questions which the first question was "What images or characteristics come to mind when you think of XXX as a vacation destination?" that represent the functional attributes of overalls image destination. The first question proposed then adjusted with Top-ofMind (TOM) association to study destination image (Stepchenkova and Li, 2014) and the result showed that TOM data can give researchers at least half a clue to an arduous question about image. Moreover, TOM could be a starting point of any story depicted by a tourist about their visit to a destination (Slak Valek and Williams, 2018), and the result showed that top-of-mind tourist's image of destination was different across culture. These also to conclude that the first thing that comes to tourists' mind about a place or destination is considered as favourable or might be the most salient in their memory. This conducted study uses the concept of Top of Mind to investigate image that most attached to the memory of tourists who have been to Yogyakarta be- fore.

\section{Destination Visual Image}

Pictures are considered to have a significant role in creating and communicating an image of a destination (MacKay and Fesenmaier, 2000). Moreover, pictures are regarded to be more powerful instruments for memory stimulation and individual association (Ye and Tussyadiah, 2011), and one of tourism stakeholders that use a picture or visual image to present the destination is DMO. UNWTO conveyed that Destination Management Organisation or usually simplify as DMO has a strategic function in developing destination as a coordinator of all elements that work together to make up destination. Recently, with the massive development of information and communication technology, the online platform such as website and social media is commonly used by DMO to give any information and promoting destination through visual image or video post (Molinillo et al., 2018). Visual images have a propensity to inspired tourists and motivated them to visit a destination based on which visual image or photograph they like (Ye and Tussyadiah, 2011). While DMO uses the same visual images on the website to promote and introduce a destination, nevertheless tourists might select or has one favourite on picture particularly which they feel connected to. Several pieces of research have conducted using visual images or photos to examine destination image with various techniques from Photo Elicitation-interview (Matteucci, 2013; Stone \& Nyaupane, 2019) through photo selection from some visual images collected by DMO or researcher that best-described destination to the tourist (Slak Valek \& Williams, 2018; Ye \& Tussyadiah, 2011). The result showed that tourist's selection of visual image about the place they wanted to visit in destination heavily depend on their cultural background. Moreover, different tourist chooses a diffe- 
rent picture that best describes destination particularly based on their feeling or experience.

\section{Domestic and International Tourist on Destination Image Study}

Domestic tourist refers to a resident's travel within their country of residence, infrequently have currency, language, and visa implication while international tourists have because they travel outside the country of origin Cooper, et al., 2008). UNWTO described an international tourist as: "a person who travels to a country other than that in which he/she has his/her usual residence, staying at least one night but no more than one year in the country visited and whose main purpose of visit can be classified under: pleasure, professional and other purposes (studies, health, pilgrimage)" (Ross, 1998). Based on the definition, we can conclude that domestic and international tourists at least have one main difference that refers to the geographic area because both came from a different country and hold different nationalities.

National cultures are intended to hold common value and people within a culture share common beliefs, attitudes, and behaviour (MacKay \& Fesenmaier, 2000; Triandis, 1994). It is to shows that the tourist's perception about destination possibly varies across culture and nation, and a handful of research supported this notion. Comparative studies about destination image from the perspective of domestic and international visitor has conducted before (Bonn, Joseph and Dai, 2005). The research found significant differences in destination image perception among resident, domestic and international tourists in Tampa Bay, Florida. Compare to resident and domestic tourist, the international tourists came to Tampa Bay had higher service and environmental standard in a tourist destination, it is showed that evaluation of the image varies across nation. The different perceptions of domes- tic and international tourists also found on the attributes of financial risk and service provided by destination (Quintal, Phau and Polczynski, 2014). The study conducted in the Western Australia South-West region showed that international tourists perceived higher financial risk or value of money than local tourists in destination.

UNWTO stated that representation of the image is not built from something that does not exist but rather a form of transformation from something existing (Cooper, et al., 2008). It is shown that investigating tourist's perceptions about an image that existing in their mind from previous visit is enable more effective image planning and development. Image perception of past visitors could vary across attributes and country of origin (Bonn, Joseph and Dai, 2005). Subsequently, knowing multi perceptions of a destination image is beneficial because destination image is shaped over time from experiences within destination (Slak Valek and Williams, 2018).

Research about the image of Yogyakarta as a tourist destination is limited. Based on the repository in an academic journal, three research found but none of them investigate image from the different perspective of a tourist. A study that investigated variables that influence Yogyakarta's' image found that both cognitive and affective components had contributed to the image (Khairani and Setyowardhani, 2013), this result echoing previous study conducted by destination image researchers before. Another research conducted in 2017 (Andajani, et al., 2017) showed that domestic tourists had positive image of Yogyakarta, and it influences visit intention of tourists. This present research is the first study about the different perceptions of Yogyakarta, as a destination based on tourist's geographic origin. This study is trying to scrutinize destination image from multiple perspectives (domestic and international tourist), components of image (af- 
fective and emotional) with a quantitative method, using structured and unstructured techniques. Recognizing the crucial role of image for tourism planning and development, research about destination image from various perspectives is necessary to be conducted.

\section{METHODS}

The present study is an online survey-based quantitative research using a structured and unstructured scale. The main purpose of the research is to explore and examine the differences in domestic and international tourist perception on the image of Yogyakarta as a tourist destination. A questionnaire was developed to test the main hypothesis that there is a different perception about Yogyakarta as a tourist destination between domestic and international tourists.

\section{Questionnaire}

In the situation of pandemic COVID-19 where most of tourists destination has visitation dropped dramatically and mobility of the people can easily spread the virus (UNWTO, 2020), using online questionnaire is assumed as an appropriate way to conduct survey research. An online questionnaire is fast to deliver, easy to administer, and can reach respondents globally (Sekaran and Bougie, 2016). Furthermore, it is aligned with the purpose of this study and targeted respondents.

The questionnaire was written both in English and Bahasa Indonesia, for different targeted respondents (international and domestic tourists) and it had proofread by professional certified. The online questionnaire was designed based on several previous studies about tourist destination image. It consisted of the following four parts:

Top-of-mind image of Yogyakarta. TOM response dealt with any idea that first comes to mind when respondents think about a destination (Stepchenkova and Li, 2014). This is the first part of the questionnaire, an unstructured approach to investigate tourists' perception of Yogyakarta as a destination using an open-ended question. Both domestic and international tourists proposed the same question "What comes first to your mind when you think about Yogyakarta as a tourist destination"? This technique was used by Slak Valek \& Williams (2018) to understand the most easily recalled image of destination. In this study, it is will be the clearest and salient memory a tourist could remember about their previous visitation to Yogyakarta.

Destination visual image selection. Pictorial advertising research denotes that visual stimuli are more immediately recalled and affect evaluation toward a product (Ye and Tussyadiah, 2011). It is adjusted in this study that tourists will ask to choose one picture that best describes Yogyakarta as a tourist destination. Eight pictures retrieved from Yogyakartas' DMO official website (www.visitingjogja.com) has been selected based on the criteria as the most liked and commented pictures by a user of the website in each type of tourism. Those pictures (Figure 1.) depicted several kinds of tourist attractions in Yogyakarta across from nature, culture, historical site, and building that represent Yogyakarta.

Cognitive evaluation of destination image. It is including several attributes that developed and self-administrated from an extensive literature review and previous studies (Baloglu \& Mangaloglu, 2001; Liu et al., 2017) subsequently adjusted with the condition of Yogyakarta as a tourist destination. To examine cognitive evaluation, the Likert scale was used in this study. It is consisting of the same 14 attributes for both domestic and international tourists then 1 more attribute about easiness to find English speaking local people added to the questionnaire for international tourists. This is based on the reason that internatio- 


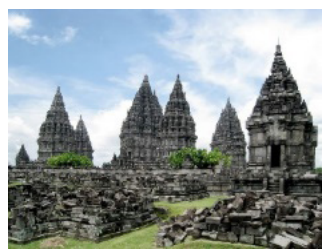

Option 1

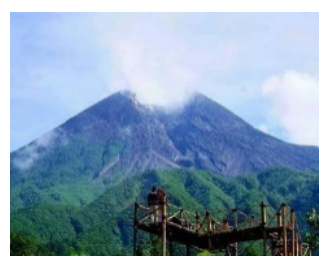

Option 5

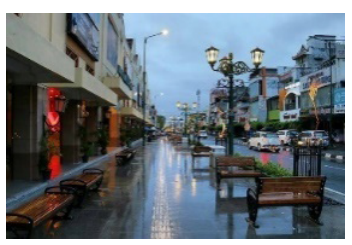

Option 2

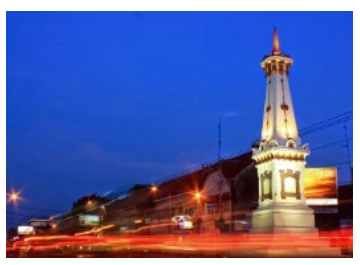

Option 6

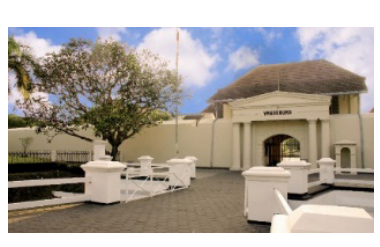

Option 3

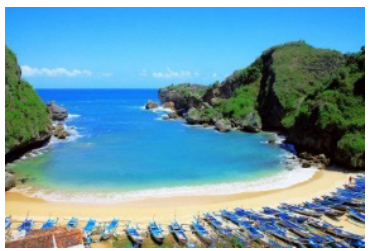

Option 7

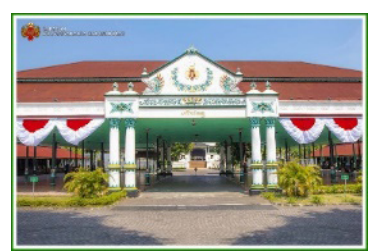

Option 4

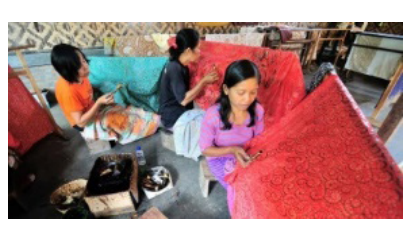

Option 8

Figure 1. Visual Image of Yogyakarta. 1. Sewu temple, 2. Malioboro street, 3. Vredeburg Fort Museum, 4. Sultan Palace, 5. Merapi Mountain, 6. Tugu monument, 7. Ngrenehan beach, 8. Making batik in Giriloyo tourism village.

nal tourist speaks in a different language from local people and the broadest language use in the world and used as a global language is English (Rao, 2019). Respondents were asked to rate all statements regarded cognitive attribute of image on a 5 -point scale from $1=$ Strongly Disagree to 5=Strongly Agree.

Affective evaluation of destination image. Many previous studies before suggested to emphasize both cognitive and affective components when studying about image (Baloglu, 2001; Khairani \& Setyowardhani, 2013). In this study, four attributes of affective evaluation that first proposed by Russel in 1980 and has been using in many studies of image afterward (Baloglu and Brinberg, 1997) is used. Like cognitive evaluation, the Likert scale is using to examine this component, and respondents were asked to rate four statements about Yogyakarta on a 5-point scale, ranging from Strongly Disagree (number 1) to Strongly Agree (number 5).

\section{Sample}

One of the main disadvantages of conducting a survey through an online questionnaire is dealing with sampling is- sue (Sekaran and Bougie, 2016) still, we can confidently say that this study used a non-probability, convenience sampling and it means that the statistical sampling bias applies. In this research, the sample constituted domestic and international tourists who have visited Yogyakarta before. The main criteria for the respondent were their last travel to Yogyakarta maximum of three years ago or in 2017. The three years was implemented because the government strategic plan about tourism in Yogyakarta is arranged every five years so that within 3 years there is no major change and tourist still well remembered about their last visit. The next criteria were based on the definition of tourist, which they should stay overnight, spend at least one night (24 hours) to one year maximum in Yogyakarta. In terms of domestic tourists, they should not originally from Yogyakarta Special Region.

\section{Data collection and Analysis}

Data were collected using an online questionnaire through any social media network such as Facebook, Instagram, LinkedIn, and WhatsApp during August to September 2020. A total of 345 questionnaires were filled out by respondents which 
involved 217 domestic tourists and 128 international tourists. 41 data were screened out due to double response, incomplete filled out, and did not match with the criteria (ex. visited Yogyakarta more than 3 years from 2020, originally from Yogyakarta for domestic tourist). Total 195 responses from domestic tourists and 109 responses from international tourists were processed and analysed using SPSS.

Data for each target group were collected separately in two databases, one for domestic tourists and one for international. Subsequently, the two databases were merged into one SPSS file to proceeds with a comparison test and further analysis. One attribute of cognitive component (English speaking local people) in questionnaire for international tourist was analysed separately and will discuss further. After combined in a single database a descriptive statistical analysis was conducted for all the questions in the questionnaire (Mean, Median, Standard Deviation). Later on, it is found that the frequency of data was not normally distributed thus, a non-probability approach was selected to examines the significant differences between domestic and international tourists, the Mann-Whitney u-test was run.

\section{RESULT AND DISCUSSION}

The majority of respondents who represented both domestic and international tourists were female and young people between 16-25 years old as shown in Table 1. Of domestic tourist respondents, $55.4 \%$ were females and $44.6 \%$ were males. The majority $(45.6 \%)$ were aged $16-25 \%$, and only $1 \%$ were older than 55 years old. Most domestic tourists commonly from different provinces in Java Island $(77.9 \%)$, with the highest percentage, were from Central Java (25.1\%). Most domestic tourists have visited Yogyakarta more than 10 times $(47.2 \%)$. The finding of frequency of domestic tourist visitation shows that they are mostly a repeater is indicated that Yogyakarta as a main domestic tourist destination.

A typical international tourist respondent was also female, 16-25 years old, of Asian nationality and first-timer. Most international tourist respondents were female $(53.2 \%), 45 \%$ were male and $1.8 \%$ were non-binary and young people aged between 16-25 were the majority (67\%). The majority of international tourist respondent was from Asia (66.1\%), followed by Europe $(19.3 \%)$. More than $50 \%$ of international tourist respondents have visited Yogyakarta once (57.8\%). Even though this study did not count on population and sampling ratio proportionally, still from the demographic background of respondents it is showed a similar result of tourist visit to Yogyakarta from the data that published by Statistical Office. In 2019 domestic tourist visited Yogyakarta was mostly from Java with the biggest percentage was Central Java followed by East Java then Jakarta (Dinas Pariwisata DIY, 2019). Still, based on the statistical data, international tourists visited Yogyakarta mostly from Asia (39\%) then followed by Europe (19\%). In this study, Asian tourists visited Yogyakarta mostly from South-East Asia, Japan, and South Korea while European tourists mostly from Dutch, Germany, and France. The majority international tourists visit Yogyakarta was young age between 16-25 years and the occupation were mostly student (30.3\%) followed by employee (23.9\%) and the rest of $45.8 \%$ were varied. It is shown that the image attached to Yogyakarta as a city of a student was confirmed in this study. Similarly, for domestic tourists total of $30.3 \%$ were students followed by teachers $19.5 \%$ then employees $13.3 \%$ and the rest $36.9 \%$ were varied.

\section{Top of Mind Image}

The top-of-mind result showed that e-ISSN 2407-392X. p-ISSN 2541-0857 
Table 1. The Demographic of Respondents

\begin{tabular}{|c|c|c|c|c|c|}
\hline \multirow{2}{*}{\multicolumn{2}{|c|}{$\begin{array}{l}\text { Variable } \\
\text { Frequency }(\mathrm{N})\end{array}$}} & \multicolumn{2}{|c|}{ Domestic Tourist } & \multirow{2}{*}{\multicolumn{2}{|c|}{$\begin{array}{l}\text { International Tourist } \\
\text { Percentage } \\
(100 \%)\end{array}$}} \\
\hline & & \multirow{2}{*}{$\begin{array}{c}\begin{array}{c}\text { Percentage } \\
(100 \%)\end{array} \\
87\end{array}$} & \multirow{2}{*}{$\begin{array}{c}\text { Frequency } \\
(\mathrm{N}) \\
44.6 \%\end{array}$} & & \\
\hline Gender: & Male & & & 49 & $45 \%$ \\
\hline & Female & 108 & $55.4 \%$ & 58 & 53.2 \\
\hline & Non-binary & 0 & & 2 & 1.8 \\
\hline \multicolumn{6}{|c|}{ Age group: } \\
\hline & $16-25$ & 89 & $45.6 \%$ & 73 & $67 \%$ \\
\hline & $26-35$ & 60 & $30.6 \%$ & 23 & $21.1 \%$ \\
\hline & $36-45$ & 16 & $8.2 \%$ & 8 & $4.6 \%$ \\
\hline & $46-55$ & 28 & $14.3 \%$ & 4 & $3.7 \%$ \\
\hline & Above 55 & 2 & $1.0 \%$ & 4 & $3.7 \%$ \\
\hline \multicolumn{6}{|c|}{$\begin{array}{l}\text { Place of Ori- } \\
\text { gin: }\end{array}$} \\
\hline & Jakarta, Capital City & 29 & $14.9 \%$ & & \\
\hline & West Java and Banten & 33 & $16.9 \%$ & & \\
\hline & Central Java & 49 & $25.1 \%$ & & \\
\hline & East Java & 41 & $21 \%$ & & \\
\hline & Sumatra & 17 & $8.7 \%$ & & \\
\hline & Kalimantan & 13 & $6.7 \%$ & & \\
\hline & Sulawesi & 6 & $3.1 \%$ & & \\
\hline & Bali & 2 & $1.02 \%$ & & \\
\hline & West Nusa Tenggara & 3 & $1.5 \%$ & & \\
\hline & Papua & 2 & $1.02 \%$ & & \\
\hline & Africa & & & 2 & $1.8 \%$ \\
\hline & America & & & 72 & $2.8 \%$ \\
\hline & Asia & & & 3 & $66.1 \%$ \\
\hline & Australia & & & 11 & $10.1 \%$ \\
\hline & Europe & & & 21 & $19.3 \%$ \\
\hline \multicolumn{6}{|c|}{ Timed Visit: } \\
\hline & 1 & 15 & $7.7 \%$ & 63 & $57.8 \%$ \\
\hline & $2-4$ & 48 & $24.6 \%$ & 33 & $30.3 \%$ \\
\hline & $5-7$ & 32 & $16.4 \%$ & 4 & $3.7 \%$ \\
\hline & $8-10$ & 8 & $4.1 \%$ & 0 & $0 \%$ \\
\hline & $>10$ & 92 & $47.2 \%$ & 9 & $8.2 \%$ \\
\hline Total & & 195 & $100 \%$ & 109 & $100 \%$ \\
\hline
\end{tabular}

what respondents' first think about Yogyakarta was varies from physical to more psychological attributes. Many responses wrote by the respondent is vary from an ob- ject; the name of a place; tourist attractions through feeling, attitude, and mood; cognitive and affective even conative, and those should be categorized carefully. Based on 
frequency analysis we seek words mentioned frequently and many similar words were categorized in one certain attribute, a temple, Borobudur, and Sultan Palace were merged as history and heritage sites for instance. The domestic tourist respondent top-of-mind results put art and culture on the top $(20 \%)$, followed by positive evaluation $(15 \%)$ such as fun, comfort, good, chill, relax and so on. Some unique characteristics that more psychologically rather than physically like classic, traditional, exotic, and 'special' accounted for $9 \%$ of domestic respondents. It is about emotion, feeling, mood, and ambiance they experienced when they were in Yogyakarta and $1 \%$ wrote negative evaluation which was a traffic jam.
As shown in Table 2., the result of the top-of-mind image in domestic tourist respondents had slightly different from international tourists. The first thing that they can recall about Yogyakarta, 40\% were history and heritage sites (which $63 \%$ of it mentioned Borobudur), followed by art and culture $(16 \%), 13 \%$ wrote a positive evaluation about Yogyakarta, 6\% of international tourist respondent were thinking about nature followed by Malioboro, friendly people and culinary took equal percentage $(5 \%)$. Surprisingly $5 \%$ were thinking about negative evaluation like traffic jams and hot climate. Interestingly, 1 respondent mentioned an irrelevant thing about Yogyakarta, it was Mount Bromo that located in East Java.

Table 2. Tourists' Top-of-Mind Image

\begin{tabular}{|c|c|c|c|c|}
\hline \multirow[b]{2}{*}{ Top of Mind Image Category } & \multicolumn{2}{|c|}{ Domestic Tourist } & \multicolumn{2}{|c|}{ International Tourist } \\
\hline & $\begin{array}{l}\text { Frequency } \\
\text { (N) }\end{array}$ & $\begin{array}{l}\text { Percentage } \\
\quad(\%)\end{array}$ & $\begin{array}{l}\text { Frequency } \\
(\mathrm{N})\end{array}$ & $\begin{array}{l}\text { Percentage } \\
(\%)\end{array}$ \\
\hline $\begin{array}{l}\text { Art and Culture: city of culture, } \\
\text { rich in culture, cultural destina- } \\
\text { tion, cultural highlight, art }\end{array}$ & 39 & $20 \%$ & 18 & $16 \%$ \\
\hline $\begin{array}{l}\text { History and Heritage sites: temple, } \\
\text { Borobudur, Prambanan, Ratu } \\
\text { Boko }\end{array}$ & 25 & $13 \%$ & 44 & $40 \%$ \\
\hline Nature: mountain, beach & 14 & $7 \%$ & 7 & $6 \%$ \\
\hline Shopping: Malioboro street & 24 & $12 \%$ & 5 & $5 \%$ \\
\hline $\begin{array}{l}\text { Culinary: coffeeshops, gudeg, } \\
\text { street food }\end{array}$ & 28 & $14 \%$ & 5 & $5 \%$ \\
\hline Friendly people & 7 & $4 \%$ & 5 & $5 \%$ \\
\hline Cheap price & 9 & $5 \%$ & 0 & $0 \%$ \\
\hline $\begin{array}{l}\text { Unique characteristics: classic, } \\
\text { traditional, exotic, special 'Jogja } \\
\text { istimewa', romantic, memory, } \\
\text { diverse, going home }\end{array}$ & 17 & $9 \%$ & 4 & $4 \%$ \\
\hline $\begin{array}{l}\text { Positive Impression: fun, comfort, } \\
\text { calm, good, wonderful, chill, relax }\end{array}$ & 30 & $15 \%$ & 15 & $13 \%$ \\
\hline $\begin{array}{l}\text { Negative Impression: traffic jam, } \\
\text { hot climate }\end{array}$ & 2 & $1 \%$ & 5 & $5 \%$ \\
\hline Irrelevant answer: Mount Bromo & 0 & $0 \%$ & 1 & $0.9 \%$ \\
\hline Total & 195 & $100 \%$ & 109 & $100 \%$ \\
\hline
\end{tabular}


An interesting finding in this study is mostly international tourist respondents (26\%) were thinking about Borobudur when they recalled Yogyakarta. Borobudur is one of the biggest and famous Buddhist temples has been listed as a world heritage site by UNESCO since 1991 (Hampton, 2005). Borobudur temple is located not in Yogyakarta Special Region area, it is in Magelang, Central Java Province about $40 \mathrm{~km}$ from the city of Yogyakarta and it is easy to access. It is shown that international tourist who visits Yogyakarta also visits area nearby which possibly effect on the length of stay and it is the problem that stakeholder acknowledges in the last two decades (Dinas Pariwisata DIY, 2019). Borobudur, Prambanan, and Ratu Boko temple are under management by Taman Wisata Candi (TWC) an entity entrusted with the care of those temples and become the most significant attractions for international tourists (Timothy and Wall, 1997). Based on the result, it might be that international tourists only passing through Yogyakarta to visit Borobudur or temples around then moving on. Yogyakarta has been long known as a centre for cultural tourism. This notion is supported by the result of this study. The number of $20 \%$ domestic tourist respondents and $16 \%$ international respondents are recalled art and culture at the top-of-mind. This percentage number could be bigger if we merged both category history and heritage sites with art and culture together because indeed, Borobudur and other temples nearby is cultural heritages. Another prominent finding of the difference of top-of-mind image for the domestic and international respondents is about shopping and culinary. The number of $12 \%$ domestic respondents recalled Malioboro (the main shopping attraction in Yogyakarta for tourists) at top-of-mind and $14 \%$ recalled culinary. While Borobudur becomes a most significant attraction for international tourists, Malioboro seems to be the most favourite attraction for domestic tourists and this is reminding us of the anecdote 'you never been to Yogyakarta if you have not gone to Malioboro'. Further, this result is corroborated by finding in destination visual image.

Last, in the top-of-mind image, the salient percentage also shown in positive attributes. Both domestic and international tourist recalled Yogyakarta as a good place physically and psychologically. The unique characteristic of Yogyakarta was also evaluated in a positive sense. Unfortunate$1 y$, the number of $5 \%$ international tourist respondent recalled negative things about Yogyakarta by its hot weather and heavy traffic jammed. It might be influenced by tourist country of origin. Four international tourist respondents give a response about hot climate is originally came from Japan, a one of Asian sub-tropical country. Compared to Indonesia as a tropical country, this response is rationally acceptable.

\section{Destination Visual Image Selection}

It is clearly shown in Table 3., that most international tourist respondents (76\%) choose Temple as the best picture to describe Yogyakarta as a tourist destination while the sizeable of domestic tourist respondent $(41.5 \%)$ choose Malioboro followed by Tugu Monument and Temple with the same percentage (18.5\%). The descriptive analysis from which photograph was frequently chosen by respondents showed that there are distinct differences between domestic and international tourists' perception of the image of Yogyakarta based on their preference for visual image provide, more than in top-of-mind image which quite diverse. In this destination visual image selection, the result is sharp describes.

Pictures or photographs are considered to be more potent instruments for memory stimulation and personal association (Ye and Tussyadiah, 2011). The result showed that domestic tourist respondents

e-ISSN 2407-392X. p-ISSN 2541-0857 
associate Yogyakarta with Malioboro, then Tugu Monument and Temple while, a majority of international respondents associate Yogyakarta with Temple. Even though this finding is must be prudently to be generalized because of the non-probability sampling issue, more investigation certainly needs to conduct as a follow up of this study. Yogyakarta, in a massive study, is mentioned as the centre of Javanese culture (Hampton, 2005; Timothy \& Wall, 1997; Yusuf, 2017) and Temple is associates with culture, it is a cultural and heritage site. Culture seems to be the most significant attractiveness for international tourist respondents who have visited Yogyakarta before, and it is important to build acknowledgment of foreign tourists about this Yogyakartas' wealthiness. As mentioned before that image is better as a transformation of something existing rather than build from something new so that it needs to be considered by tourism authorities in Yogyakarta to strengthen this cultural image if they targeted more international visitors. It is not solely relying on cultural and heritage attractions nearby such Borobudur temple nevertheless invigorates cultural attractions that existing in Yogyakarta is considered to be more important.

In contrast, the propensity to associate Yogyakarta with Malioboro is obvious in domestic tourist responses. Malioboro is the main street or area in Yogyakarta where the majority of the city's attraction (Timothy and Wall, 1997). It is the busiest street in Yogyakarta with variety stores, street vendors that sells enticing goodies from souvenirs and craft, dining place, street food stall, a street busker and various affordable accommodation nearby. Malioboro is the main shopping street in Yogyakarta, a very well-known and possibly the main attraction, especially for domestic tourists. Another visual image chooses by domestic tourist respondents in salient numbers $(18.5 \%)$ is Tugu Monument. It is a popular landmark in Yogyakarta located in the Yogyakarta city center about less than $2 \mathrm{~km}$ from Malioboro. Both Malioboro and Tugu Monument to be like 'a must visit place' in Yogyakarta for domestic tourist. As the busiest street and popular landmark on the colonnaded street from north to south, various events are frequently held in those places like a carnival, cultural parade, carfree day even mass protest. The implication of Malioboro and Tugu monuments' popularity for domestic tourist is causing crowd and congestion in the area nearby. This is the issue that the tourism authority in Yogyakarta should be considered and some strategic planning need to be addressed.

\section{Perceived Destination Image (Cognitive and Affective Evaluation)}

A reliability analysis was performed for the perceived destination image of Yogyakarta scale. It is comprising 4 items in affective evaluation and 14 items plus 1 more item in cognitive evaluation about easiness to find English speaking local people in Yogyakarta for international tourist. Based on Cronbach's alpha value, 0.86 for cognitive evaluation and 0.800 for affective evaluation it means that both questionnaires for domestic and international tourists achieved high internal consistency. After the reliability test is conducted the next step that must be done to proceed a significant difference between domestic and international tourist respondents is to find the Mean (M) and Standard Deviation (SD). To further identify the significant differences between domestic and international tourists, a distribution analysis is conducted to test the normality of data frequency. Based on the SPSS analysis, the findings show that cognitive and affective evaluation of image data frequency were not normally distributed thus, a non-parametric approach to the distribution analysis was selected. A Mann-Whitney u-test is selected to identify significant differences 
between both groups of respondents on the cognitive and affective image of Yogyakarta as a tourist destination (Table 4).

Based on the Mann-Whitney u-test the result shows that there is significant different on the cognitive evaluation image of Yogyakarta as a tourist destination from the perspective domestic and international tourists (p-value 0.0001) nevertheless, there is no significant different in affective evaluation ( $p$-value 0.282 ). The table below shows descriptive analysis on domestic and international tourist responses about attributes of image in both components (Table $5)$.

The result shows that both domestic and international tourist respondents are strongly agreed on most of attributes in cognitive evaluation which are good accommodation, beauty of natural sceneries, appealing local culinary, interesting cultural attraction as well as historical sites. In more psychological attributes, both are also strongly agreed that Yogyakarta is a safe destination with nice weather and friendly local people. Moreover, Yogyakarta is kind of destination that offers valuable of money and for domestic tourist, it also has long been known that compare to other most visited destinations in Indonesia such as Jakarta and Bali, Yogyakarta is considered as a low-cost living region.

In the attribute about general infrastructure, the level of agreement between domestic and international tourists is different whereas domestic respondents showed strongly agree $(\mathrm{M}=4.18)$ and international respondent response agree $(\mathrm{M}=3.43)$. Infrastructure seems to become a common issue in developing countries. Many developing countries that depend on the tourism sector for economy, tend to focus their tourism planning on the development and distribution of infrastructure and facilities (Timothy and Wall, 1997). The infrastructure work in Indonesia seems endless and is always carried out throughout the year from loading-unloading or built-rebuilt a road, airport, facilities in tourist attraction and so on. This infrastructure problem possibly affects the image of a destination especially in developing countries like Indonesia.

The level of agreement in the three attributes about transportation system, cleanliness, and TIC (Tourism Information Centre) are not as strong as other attributes nevertheless both domestic and international tourist respondent still agree that Yogyakarta is clean, has a good transportation system and good service of TIC. This finding could be considered by the tourism authority in Yogyakarta to increase the service on TIC, cleanliness, and accessibility in tourist attractions. For international tourist respondents, they do agree $(\mathrm{M}=3.57)$ that it is easy to find English speaking local people.

Interestingly, in all affective attributes of image both domestic and international tourist respondents are fully agreed that Yogyakarta is a pleasant, arousing, rela-

Table 4. Mann-Whitney u-test for Perceived Destination Image in Cognitive and Affective Components

\begin{tabular}{lcccc}
\hline & \multicolumn{4}{c}{ Total } \\
\cline { 2 - 5 } & Mann-Whitney U & Wilcoxon W & Z & Asymp. Sig. (2-tailed) \\
\hline Cognitive & 8151.500 & 14146.500 & -3.373 & 0.001 \\
Evaluation & & & & 0.282 \\
Affective & 9865.500 & 15.860 .500 & -1.076 & 0.0 \\
Evaluation & & & &
\end{tabular}

Significant at the level $\alpha=0,05$ 
Table 5. Mean, Standard Deviation and Level of Agreement for Destination Image (Cognitive and Affective Evaluation)

\begin{tabular}{|c|c|c|c|c|c|c|}
\hline Component and Attributes of Image & $\begin{array}{l}\text { Type of } \\
\text { Tourist }\end{array}$ & $\mathrm{N}$ & M & SD & $\begin{array}{l}\mathrm{SD} \\
\text { Error }\end{array}$ & $\begin{array}{l}\text { Level of } \\
\text { Agreement }\end{array}$ \\
\hline \multicolumn{7}{|l|}{ Cognitive: } \\
\hline \multirow{2}{*}{$\begin{array}{l}\text { Yogyakarta has a variety of good quality } \\
\text { accommodation }\end{array}$} & Domestic & 195 & 4.35 & .659 & .047 & Strongly Agree \\
\hline & International & 109 & 4.28 & .837 & .080 & Strongly Agree \\
\hline \multirow{2}{*}{$\begin{array}{l}\text { Yogyakarta has a good quality infrastruc- } \\
\text { ture and public facilities }\end{array}$} & Domestic & 195 & & .744 & .053 & Strongly Agree \\
\hline & International & 109 & 3.43 & .994 & .095 & Agree \\
\hline \multirow{2}{*}{$\begin{array}{l}\text { Yogyakarta has a good transportation } \\
\text { system }\end{array}$} & Domestic & 195 & & .958 & .069 & Agree \\
\hline & International & 109 & 3.31 & 1.046 & .100 & Agree \\
\hline \multirow{2}{*}{$\begin{array}{l}\text { Yogyakarta has beautiful natural scenery } \\
\text { and attractions (ex: beaches, mountain) }\end{array}$} & Domestic & 195 & 4.64 & .597 & .043 & Strongly Agree \\
\hline & International & 109 & 4.68 & .575 & .055 & Strongly Agree \\
\hline \multirow{2}{*}{$\begin{array}{l}\text { Yogyakarta offers interesting cultural at- } \\
\text { tractions or events }\end{array}$} & Domestic & 195 & 56 & .626 & .045 & Strongly Agree \\
\hline & Internation & 109 & & & .057 & Stro \\
\hline \multirow{2}{*}{$\begin{array}{l}\text { Yogyakarta has interesting historical at- } \\
\text { tractions and sites }\end{array}$} & Domestic & 195 & 4.64 & .551 & .039 & Strongly Agree \\
\hline & International & 109 & & & .052 & Strongly Agree \\
\hline \multirow{2}{*}{$\begin{array}{l}\text { Yogyakarta provides appealing local } \\
\text { cuisines }\end{array}$} & Domestic & 195 & 4.46 & .788 & .056 & Agree \\
\hline & Internati & 109 & & .7 & .069 & Strongly Agree \\
\hline \multirow[t]{2}{*}{ Yogyakarta is a clean tourist destination } & Domestic & 195 & 3.91 & .87 & .063 & Agree \\
\hline & Internat & 109 & 3.33 & & .104 & $\mathrm{Ag}$ \\
\hline \multirow{2}{*}{$\begin{array}{l}\text { Yogyakarta has enjoyable shopping places } \\
\text { and souvenir stores }\end{array}$} & Domestic & 195 & 4.33 & .730 & .052 & Strongly Agree \\
\hline & Inte & 109 & 4.19 & .85 & .082 & Agree \\
\hline \multirow[t]{2}{*}{ Yogyakarta is a safe place for tourists } & Domestic & 195 & 4.09 & .869 & .062 & Agree \\
\hline & International & 109 & 4.08 & .934 & .089 & Strongly Agree \\
\hline \multirow{2}{*}{$\begin{array}{l}\text { Yogyakarta has nice weather for strolling } \\
\text { around }\end{array}$} & Domestic & 195 & 4.16 & .864 & .062 & Agree \\
\hline & International & 109 & 4.07 & .879 & .084 & Strongly Agree \\
\hline \multirow{2}{*}{$\begin{array}{l}\text { Local people in Yogyakarta are nice and } \\
\text { friendly }\end{array}$} & Dor & 195 & & .593 & .042 & Agree \\
\hline & International & 109 & 4.77 & .538 & .052 & Strongly Agree \\
\hline $\begin{array}{l}\text { It is easy to find English speaking local } \\
\text { people in Yogyakarta }\end{array}$ & International & 109 & 3.57 & & & \\
\hline \multirow{2}{*}{$\begin{array}{l}\text { The Tourism Information Centre (TIC) is } \\
\text { easy to access and offers a good service }\end{array}$} & Domestic & 195 & 3.94 & .889 & .064 & Agree \\
\hline & International & 109 & 3.31 & .988 & .095 & Agre \\
\hline \multirow{2}{*}{$\begin{array}{l}\text { Yogyakarta is a place that offers value for } \\
\text { money }\end{array}$} & Domestic & 195 & 4.58 & .624 & .045 & Strongly Agree \\
\hline & International & 109 & 4.35 & .821 & .079 & Strongly Agree \\
\hline \multicolumn{7}{|l|}{ Affective: } \\
\hline \multirow{2}{*}{$\begin{array}{l}\text { Yogyakarta is a pleasant tourist destina- } \\
\text { tion }\end{array}$} & Domestic & 195 & 4.68 & .509 & .036 & ly Agree \\
\hline & International & 109 & 4.67 & .594 & .057 & Strongly Agree \\
\hline \multirow{2}{*}{$\begin{array}{l}\text { Yogyakarta is an arousing tourist destina- } \\
\text { tion }\end{array}$} & Domestic & 195 & 4.51 & .595 & .043 & Strongly Agree \\
\hline & International & 109 & 4.26 & .886 & .085 & Strongly Agree \\
\hline \multirow{2}{*}{$\begin{array}{l}\text { Yogyakarta is a relaxing tourist destina- } \\
\text { tion }\end{array}$} & Domestic & 195 & 4.43 & .717 & .051 & Strongly Agree \\
\hline & International & 109 & 4.30 & .908 & .087 & Strongly Agree \\
\hline \multirow{2}{*}{$\begin{array}{l}\text { Yogyakarta is an exciting tourist destina- } \\
\text { tion }\end{array}$} & Domestic & 195 & 4.59 & .588 & .042 & Strongly Agree \\
\hline & International & 109 & 4.60 & .722 & .069 & Strongly Agree \\
\hline TOTAL & & 304 & & & & \\
\hline
\end{tabular}

Scale: $1=$ Strongly disagree; $2=$ Disagree; $3=$ Not sure; $4=$ Agree; $5=$ Strongly Agree

http://ojs.unud.ac.id/index.php/eot 
xing, and exciting tourist destination. Furthermore, no significant differences were found in this affective component of image. This positive response about Yogyakarta is should be maintained by increasing service from all tourism stakeholders. The wealthiness of cultural attractions, friendliness of local people with valuable of money is a combination that possibly could determine visit intention of tourist.

\section{CONCLUSION}

This study again, confirming previous studies about an image that show image perception could differ across culture and country of origin. There is a significant difference in the destination visual image and cognitive evaluation. Nevertheless, there is no significant difference in the affective evaluation of image, both tourists have positive emotions when they were in Yogyakarta. In the top-of-mind image, international tourists recalled Borobudur temple as the place that they remember most about Yogyakarta while domestic tourists recalled Malioboro. The destination visual image gives a clearer insight into this. Yogyakarta that has long been known as the city of culture with friendly local people and unique characteristic are the attached image that tourist perceives so far is justified in this study. International tourists, in particular, are not generally aware of the wealthiness of cultural and also natural attractions in Yogyakarta so practically this study could support tourism stakeholders to design tourism planning, promotion and segmentation of the tourism product. Furthermore, the infrastructure and congestion issue also need to be considered as something that might be distorted image of Yogyakarta that most perceive as a good tourist destination in many attributes.

\section{LIMITATION}

http://ojs.unud.ac.id/index.php/eot
The basic limitation of using convenience sampling like in this study is the reader should remain about take generalization of the result and interpretation carefully even though the main result of this study is supported by previous research. Conducting an online survey seems very common recently, researchers also need to be aware especially about the disadvantage related to limited respondents involved in the survey. For further research tourist, data should be gathered according to nationality proportionally so a comprehensive cross-cultural examination would be clearer.

\section{ACKNOWLEDGMENT}

This research was fully funded by the Inter-Culture Department, Faculty of Cultural Sciences UGM. I would like to highly give appreciation to all enumerators for their efforts in collecting data online.

\section{REFERENCES}

Andajani, S.T., M.M., E., Junaidi, A. A. and Widjaja, F. N. (2017). The effect of yogyakarta destination image on behavioral intentions on domestic tourist. Journal of Management and Business. doi: 10.24123/jmb.v16i1.294.

Baloglu, S. (2001) 'Image variations of Turkey by familiarity index: informational and experiential dimensions', Tourism Management. doi: 10.1016/ s0261-5177(00)00049-2.

Baloglu, S. and Brinberg, D. (1997) 'Affective images of tourism destinations', Journal of Travel Research. doi: $10.1177 / 004728759703500402$.

Baloglu, S. and Mangaloglu, M. (2001) 'Tourism destination images of Turkey, Egypt, Greece, and Italy as perceived by US-based tour operators and travel agents', Tourism Management. 
doi: $10.1016 / \mathrm{S} 0261-5177(00) 00030-$ 3.

Baloglu, S. and McCleary, K. W. (1999) 'A model of destination image formation', Annals of Tourism Research. doi: 10.1016/S0160-7383(99)00030-4.

Biro Pusat Statistik (2018) Statistik Wisatawan Nusantara, Biro Pusat Statsitik.

Bonn, M. A., Joseph, S. M. and Dai, M. (2005) 'International versus domestic visitors: An examination of destination image perceptions', Journal of Travel Research. doi: $10.1177 / 0047287504272033$.

Chen, C. F. and Tsai, D. C. (2007) 'How destination image and evaluative factors affect behavioral intentions?', Tourism Management. doi: 10.1016/j. tourman.2006.07.007.

Coban S (2012) 'The effects of the image of destination on tourist satisfaction and loyalty: The case of Cappadocia', European Journal of Social Sciences.

Cooper, Chris; Fletcher, John; Fyall Alan; Gilbert, David; \& Wanhill, S. (2008) Tourism Principles and Practice. Fourth Edi. London: Prentice Hall.

Crompton, J. L. (1979) 'An assessment of the image of Mexico as a vacation destination and the influence of geographical location upon that image', Journal of travel research, 17(4), pp. 18-23.

Dinas Pariwisata DIY (2019) 'Statistik Kepariwisataan 2019', Dinas Pariwisata Daerah Istimewa Yogyakarta.

Echtner, C. M. and Ritchie, J. R. B. (1993) 'The Measurement of Destination Image: An Empirical Assessment', Journal of Travel Research. doi: 10.1177/004728759303100402.

Fakeye, P. C. and Crompton, J. L. (1991) 'Image Differences between Prospec-

http://ojs.unud.ac.id/index.php/eot tive, First-Time, and Repeat Visitors to the Lower Rio Grande Valley', Journal of Travel Research. doi: 10.1177/004728759103000202.

Gallarza, M. G., Saura, I. G. and García, H. C. (2002) 'Destination image: Towards a conceptual framework', Annals of Tourism Research. doi: 10.1016/S0160-7383(01)00031-7.

Gartner, W. C. (1994) 'Image formation process', Journal of travel \& tourism marketing, 2(2-3), pp. 191-216.

Hampton, M. (2005) 'Heritage, local communities and economic development', Annals of Tourism Research. doi: 10.1016/j.annals.2004.10.010.

Hunter, W. C. (2008) 'A typology of photographic representations for tourism: Depictions of groomed spaces', Tourism Management. doi: 10.1016/j.tourman.2007.03.008.

Kemenpar (2018) 'Data Kunjungan Wisatawan Mancanegara Bulanan Tahun 2018', Kemenpar.

Khairani, K. and Setyowardhani, H. (2013) 'Analysis on Variables Affecting the Creation of Tourist Destination Image: Case Study on Domestic Tourists Visiting Yogyakarta between 2007 to 2009', ASEAN Marketing Journal. doi: 10.21002/amj.v2i1.1992.

Konecnik, M. and Gartner, W. C. (2007) 'Customer-based brand equity for a destination', Annals of tourism research, 34(2), pp. 400-421.

Kotler, P. and Gertner, D. (2002) 'Country as brand, product, and beyond: A place marketing and brand management perspective', Journal of Brand Management. doi: 10.1057/palgrave. bm.2540076.

Law, R., Kozak, M. and Crotts, J. C. (2007) 'The impact of the perception of risk e-ISSN 2407-392X. p-ISSN 2541-0857 
on international travellers.', International Journal of Tourism Research.

Liu, X., Li, J. J. and Kim, W. G. (2017) 'The role of travel experience in the structural relationships among tourists' perceived image, satisfaction, and behavioral intentions', Tourism and Hospitality Research. doi: 10.1177/1467358415610371.

MacKay, K. J. and Fesenmaier, D. R. (2000) 'An exploration of cross-cultural destination image assessment', Journal of travel research, 38(4), pp. 417-423.

Matteucci, X. (2013) 'Photo elicitation: Exploring tourist experiences with researcher-found images', Tourism Management. doi: 10.1016/j.tourman.2012.07.002.

Mayo, E. (1975) 'Tourism and the National Parks: A Psychographic and Attitudinal Study', Journal of Travel Research. doi: 10.1177/004728757501400103.

Molinillo, S. et al. (2018) 'DMO online platforms: Image and intention to visit', Tourism Management. doi: 10.1016/j.tourman.2017.09.021.

Nurazizah, G. R. and Marhanah, S. (2020). Influence of destination image and travel experience towards revisit intention in yogyakarta as tourist destination. Journal of Indonesian Tourism, Hospitality and Recreation. doi: 10.17509/jithor.v3i1.23016.

Prayag, G. and Ryan, C. (2012) 'Antecedents of tourists' loyalty to mauritius: The role and influence of destination image, place attachment, personal involvement, and satisfaction', Journal of Travel Research. doi: 10.1177/0047287511410321.

Quintal, V., Phau, I. and Polczynski, A. (2014) 'Destination brand image of Western Australia's South-

http://ojs.unud.ac.id/index.php/eot
West region: Perceptions of local versus international tourists', Journal of Vacation Marketing. doi: 10.1177/1356766713490163.

Rao, P. S. (2019) 'The role of english as a global language', Research Journal of English.

Ross, G. F. (1998) The Psychology of Tourism. Second edi. Melbourne: Hospitality Press Pty Ltd, Melbourne.

Santoso, S. (2019) 'Examining Relationships between Destination Image, Tourist Motivation, Satisfaction, and Visit Intention in Yogyakarta', Expert Journal of Business and Management, 7(1), pp. 82-90.

Sekaran, U. and Bougie, R. (2016) 'Research Method for Business Textbook: A Skill Building Approach', John Wiley \& Sons Ltd.

Slak Valek, N. and Williams, R. B. (2018) 'One place, two perspectives: Destination image for tourists and nationals in Abu Dhabi', Tourism Management Perspectives. doi: 10.1016/j. tmp.2018.06.004.

Stepchenkova, S. and Li, X. (2014) 'Destination image: Do top-of-mind associations say it all?', Annals of Tourism Research. doi: 10.1016/j.annals.2013.12.004.

Stone, L. S. and Nyaupane, G. P. (2019) 'The Tourist Gaze: Domestic versus International Tourists', Journal of Travel Research. doi: 10.1177/0047287518781890.

Tasci, A. D. A., Gartner, W. C. and Tamer Cavusgil, S. (2007) 'Conceptualization and Operationalization of Destination Image', Journal of Hospitality and Tourism Research. doi: 10.1177/1096348006297290.

Timothy, D. J. and Wall, G. (1997) 'Selle-ISSN 2407-392X. p-ISSN 2541-0857 
ing to tourists: Indonesian Street Ven- Ye, H. and Tussyadiah, I. P. (2011) 'Desdors', Annals of Tourism Research. doi: 10.1016/S0160-7383(97)800047. tination visual image and expectation of experiences', Journal of Travel and Tourism Marketing. doi: 10.1080/10548408.2011.545743.

Triandis, H. C. (1994) Culture and Social Behavior. Edited by F. H. Rogers, Yusuf, M. (2017) 'Measuring Tourist's Christopher; Sofer, Nomi; \& Burns. New York: McGraw-Hill, Inc.

UNWTO (2020) 'International tourism faces deepest crisis in history $\bullet '$, World Tourism Barometer. Motivations for Consuming Local Angkringan Street Food in Yogyakarta, Indonesia', Journal of Indonesian Tourism and Development Studies. doi: 10.21776/ub.jitode.2017.005.02.01. 